\title{
Spill-over Effects of Affirmative Action: Political Representation and the Power of the Elderly
}

\author{
Audinga Baltrunaite \\ Alessandra Casarico \\ Paola Profeta
}

CESIFO WORKING PAPER NO. 4955

CATEgory 1: PubliC FinANCE

SEPTEMBER 2014

An electronic version of the paper may be downloaded

- from the SSRN website: Www.SSRN.com

- from the RePEc website: Www.RePEc.org

- from the CESifo website: $\quad$ www.CESifo-group.org/wp 


\title{
Spill-over Effects of Affirmative Action: Political Representation and the Power of the Elderly
}

\begin{abstract}
There is evidence that age matters in politics. In this paper we study whether implementation of affirmative action policies on gender can generate additional effects on an alternative dimension of representation, namely, the age of politicians. We consider an Italian law which introduced gender quotas in candidate lists for local elections in 1993, and was abolished in 1995. As not all municipalities went through elections during this period, we can identify two groups of municipalities and use a Difference in differences estimation to analyze the effect of gender quotas on the age of elected politicians. We find that gender quotas are associated with election of politicians that are younger by more than one year. The effect occurs mainly due to the reduction in age of elected male politicians and is consistent with the optimizing behavior of parties or of voters.
\end{abstract}

JEL-Code: D720, J450.

Keywords: gender quotas, municipal elections, difference in differences, age.

\author{
Audinga Baltrunaite \\ IIES, Stockholm University \\ Stockholm / Sweden \\ audinga.baltrunaite@iies.su.se \\ Alessandra Casarico \\ Paola Profeta \\ Bocconi University \\ Milan / Italy \\ alessandra.casarico@unibocconi.it \\ Milan / Italy \\ paola.profeta@unibocconi.it
}

August 21, 2012

We thank for their comments and suggestions the editor, two anonymous referees, Maria De Paola and participants to the 2013 CESifo Venice Summer Institute "The Determinants of Gender Gaps: Institutional Design and Historical Factors“. 


\section{Introduction}

The issue of the age of politicians is coming to the forefront of the political debate. At the onset of the Arab spring, an article on the Economist ${ }^{1}$ pointed out that among the causes of the revolution one could name the difference between the median age of the population and the age of political leaders: autocracies show the largest gap between the two, whereas democracies seem to favor younger leaders. The rapid aging of the population may affect the age profile of the ruling class and further exacerbate the intergenerational imbalances in the political landscape observed in some countries or it can open up new challenges in countries in which the political arena is currently not completely dominated by the elderly.

In the last years many countries have tried to promote a more balanced representation in political institutions, resorting to affirmative action policies. These have generally targeted gender and ethnic minorities, in an effort to make legislatures resemble more closely the population as a whole. The low number of female politicians in local and national administrations is indeed considered a sign of lack of political representation in institutions and an obstacle to the legitimization of democratic bodies; the same type of arguments apply to the representation of ethnic minorities and may justify the adoption of affirmative action instruments. The absence of age diversity in the political arena has never prompted the implementation of any corrective measures. One can, however, wonder whether the efforts to reach a more diverse pool of politicians in terms of gender or ethnicities have also affected the age distribution of politicians, narrowing the gap between the latter and the age distribution of voters.

This paper is a first attempt to assess the role of gender quotas in influencing the age of elected politicians. With the goal to create more room for women and to rebalance gender representation in politics, gender quotas may trigger a broader renovation and rejuvenation of the political class, typically dominated by elderly male. To assess the existence of this spill-over effect, we use a quasi-natural experiment in Italy: gender quotas in candidate lists for local elections were introduced in 1993, and subsequently abolished in 1995. Since elections did not take place in all municipalities during the reform period, we can identify a treatment and a control group and adopt a Difference in differences estimation strategy (see De Paola et al., 2010, and Baltrunaite et al., 2014) to analyze the effect of gender quotas on the age of elected politicians. We show that

\footnotetext{
${ }^{1}$ February 15, 2011.
} 
gender quotas introduced with the purpose of increasing female representation, also have the effect of reducing the age of elected politicians. Thus, gender quotas may help to mitigate the ruling of "male gerontocracies".

The issue of the selection of Italian politicians is analyzed by a recent and growing literature (e.g., Merlo et al., 2009; Galasso and Nannicini, 2011; Gagliarducci and Paserman, 2012). Italy is often referred to as a country in which expertise and power are concentrated in the older male generation at the expense of the younger and of women. ${ }^{2}$

The literature proposes several arguments on why one may care about the age of leaders or decision-makers. Young leaders may have a different leadership style: Schubert (1988), for instance, finds that aging is correlated with a less active leadership approach and Schubert et al. (1987) - that being old is associated with a stronger status in collective decision making. Barbuto et al. (2007) show that there are age differences in transactional and transformational leadership styles. Simonton (1988) surveys the link between personal age and outstanding achievement in domains of creativity and leadership: one obstacle to detecting the connection between age and leadership is that most individuals fill positions of power for relatively brief spans of time which makes it hard to estimate age-productivity profiles. Focusing on careers of 25 European kings and queens from over a dozen nations, Simonton (1984) finds that most objective performance indicators either decline with age or else exhibit an inverted-U function with a peak at the 42nd year of life. If one considers decision-making within groups as an additional aspect of political activity, empirical evidence collected on teams in firms can also be relevant: Wiersema and Bantel (1992) examine the relationship between the demography of top management teams and corporate strategic change and find that the firms most likely to undergo changes in corporate strategy have top management teams characterized by lower average age. Wegge and Schmidt (2009) focus on age diversity in teams within organizations and show that it has a positive impact on performance. More generally, focusing on the productivity by age of workers at a large car manufacturer, Börsch-Supan and Weiss (2011) find that it does not decline at least up to age 60: the number of errors increases with age, but the severity of errors decreases.

Age may also affect preferences and, in the realm of politics, this may determine the implementation of different policies. Lovenduski and Norris (2003) in their study of gender differences in preferences over policies among British politicians show that also age does prove important, with the younger generation of politicians more favorable

\footnotetext{
${ }^{2}$ On the role of the cultural bias against women in the Italian labor market, see Campa et al. (2011).
} 
towards policies promoting gender equality than the older one. Age is also a relevant variable in determining voters' preferences over different policies. An extensive political economy literature has argued that our welfare states and the dominant role of pensions can be explained by intergenerational economic and political relations (Galasso and Profeta, 2004) and that the ageing process is associated with a change in size of the social security systems (Razin et al., 2002; Galasso and Profeta, 2007). Our welfare states and the dominant role of pensions can be explained by "gerontocracy", i.e. the elderly represent an interest-group which is successful in exerting political power and obtaining transfers in its favor (Mulligan and Sala-i-Martin, 2003). Age also influences the ability of voters to process information and to make a correct vote, as discussed in Lau and Redlawsk (2008).

These different strands of the literature seem to reach the conclusion that age matters in politics. Given this background, in this paper we study whether implementation of affirmative action policies on gender can generate additional effects on an alternative dimension of representation, namely, the age of politicians. The analysis builds upon Baltrunaite et al. (2014), to which we refer for a more detailed presentation of the institutional features of the reform and the methodology adopted. They show that the average level of education of elected councilors has increased, not only thanks to the higher presence of women who are on average more educated, but also to the improvement in the average quality of elected men. Besides being on average more educated than male elected politicians, elected women are on average also younger. In this paper we find that gender quotas are associated with election of politicians that are younger by more than one year. This effect is mainly due to the reduction in age of elected male politicians and is robust to controlling for political ideology and political competition. Our results may occur both due to the optimizing behavior of parties, which consider older men of a lower expected valence in gaining votes, and to the maximizing behavior of voters, who rate younger male politicians better and vote for them. We also point out that the specific context matters to assess the appropriate age profile of politicians.

The paper is organized as follows: the next section introduces the institutional framework and the data; section 3 describes our empirical strategy, section 4 shows the results and section 5 concludes. 


\section{The institutional framework and the data}

\subsection{Italian municipalities and the Law 81/1993}

There are approximately 8,100 municipalities in Italy. They vary significantly in terms of geographic, demographic and economic indicators. The municipal administration manages the registry of births and deaths, the registry of deeds, contracting for local roads and public works and, most importantly, social services. It is headed by a mayor, who is assisted by a legislative body, the municipal council (Consiglio Comunale), and an executive body, the executive committee (Giunta Comunale).

In 1993 a law concerning the electoral system for municipalities and provinces was approved. According to the Law 81/1993, neither sex could represent more than $2 / 3$ of the total candidates in electoral lists for municipal councils in municipalities with more than 15,000 residents, whereas for municipalities with less than 15,000 residents neither sex could represent more than $3 / 4$ of the total candidates. The quota system was introduced to balance the gender composition in representative institutions at local level. Namely, since usually the majority of the candidates are male, the law established that at least 1/3 $(1 / 4)$ of the positions in electoral lists had to be reserved for women. In case the list did not comply with the quota requirement, it was refused. ${ }^{3}$ In 1995 the provision regarding gender quotas was abolished by the Constitutional Court. The Judgment 422/1995 claimed that this provision was unconstitutional because in violation of the principle of equality between sexes. All the other reforms included in the Law were not modified.

As a result of the ruling, the provision on gender quotas was in effect for a short period of time between March 25, 1993 and September 12, 1995. Local elections take place every five years ${ }^{4}$ and municipal governments cannot affect their schedule. ${ }^{5}$ Given this fixed term feature, not all the Italian municipalities were affected by the reform: some municipalities voted with gender quotas, and others never did so, as if the law had never been enacted. Thereby, we identify the former as the treatment group (where

\footnotetext{
${ }^{3}$ The Law 81/1993 included other provisions besides gender quotas. See Baltrunaite et al. (2014) for details.

${ }^{4}$ With the exception of the period 1993-1999, when the mandate was shortened to four years.

${ }^{5}$ Elections can be anticipated in (arguably exogenous with respect to the introduction of quotas) instances such as the death or resignation of the mayor. Elections take place only in a specified time window of a year. If the term of the municipal council expires after this period, elections are delayed. This explains why in some municipalities the term may be longer than 5 years.
} 
treatment is defined as being exposed to gender quotas) and the latter as the control group. The first group is composed of 7,643 municipalities, which voted at least once during the period when the law was in force; the second group consists of the rest of the municipalities, in line with the strategy used by De Paola et al. (2010).

As only gender quotas were removed, whereas the other provisions introduced by Law 81/1993 remained in place, we can safely claim that gender quotas are the only different institutional feature between our treatment and control group municipalities. There are no reasons to suspect that the 1993 reform had a differential impact on the two groups of municipalities other than the gender quotas' provision.

\section{$2.2 \quad$ The data and descriptive analysis}

In our analysis we use administrative data provided by the Italian Ministry of the Interior on gender and age of all politicians elected in the Italian municipalities. The sample covers the last election before the implementation of quotas and the first election after it, which happen, for the vast majority of municipalities, during the period 1987-1999. We use these data also to identify the political ideology of the majority in each municipal council and to build a measure of political competition. In addition, data regarding the size of the resident population over age 15 and over age 65, the employment rate (overall and female) and the education level in the municipality are taken from the 1991 and 2001 Italian Census of Population.

To calculate the overall employment rate (Employment rate), the female employment rate (Female employment rate) and the education level defined as the share of university graduates (Local education level) we use the resident population over age 15. Population over age 65 is calculated as the share of old population over the total population in a given municipality. We measure political ideology using dummies for the political leaning of the majority in the council. ${ }^{6}$ The variable Left-wing majority is a dummy for a left-wing parties' majority; the variable Centre-right majority is a dummy for a center-right parties' majority; the variable Civic list majority is a dummy for councils in which the majority of members are politicians elected through civic lists and the variable Coalition majority is a dummy for councils in which seats are shared equally by two or

\footnotetext{
${ }^{6}$ Since Italian local elections are characterized by a large number of parties running for and winning the seats, in order to identify the majority we group parties according to their political leaning and then determine the majority in a given municipal council and also the remaining minority groups. Note therefore that in a municipality with, for example, a left-wing majority, we may often have councilors from several different left-leaning parties.
} 
more parties with different ideology. The degree of political competition is measured by the difference between the share of seats of the winning majority and that of the second largest group.

Table 1 reports averages of these variables in treated and control municipalities in 1991. The statistics show that, whereas the two groups do not differ in terms of resident population size, control municipalities are more likely to be in the South and they have a lower overall and female employment rate and a lower population share above age 65. Also, they are less likely to be governed by a left-wing majority and show less competition in local politics.

To motivate the further analysis, Figure 1 presents the graphical evidence of the left-ward shift of the age distribution in treatment group municipalities from the last election before the introduction of the reform to the first election after it. It is evident that the density at ages less than 40 increases, while we see fewer politicians older than 40 elected to municipal councils after the reform.

[Figure 1 here]

\section{$3 \quad$ Empirical Strategy}

In our quasi-experimental set-up, we use a Difference in differences estimation to examine the effect of gender quotas on the age of elected politicians. We identify municipalities which were exposed to gender quotas as the treatment group and municipalities which never voted with gender quotas as the control group. Then, we run a number of municipality-level regressions and compare the change in the average age of municipal councilors across the two groups of municipalities in the last election before the adoption of the law and in the first election immediately after it. Finally, we also analyze the effects on the age of elected female and male politicians separately.

Since being exposed or not to gender quotas was induced by an exogenous change in the institutional setting, we consider the treatment and the control group status unrelated to other unobserved municipality characteristics affecting the dependent variable. Moreover, in our setting selection into treatment or control groups is especially unlikely, because the timing of voting cannot be manipulated by the municipality itself due to the fixed term of local governments. ${ }^{7}$

\footnotetext{
${ }^{7}$ This is in line with Baltrunaite et al. (2014) in which the reader can find a more detailed discussion of the empirical strategy adopted.
} 
Due to staggered election dates, in our analysis we generally do not compare voting outcomes for the treatment and the control group in the same year. Roughly, "after reform elections" for the treatment group municipalities happen in the period March 1993 - September 1995, while "after reform elections" for the control group happen during the period October 1995 - July 1999. Hence, in our analysis we also implicitly assume that, in the absence of the reform, the treatment group would have had the same change in outcome as the control group during different time periods.

The baseline Difference in differences estimator is of the form:

$$
Y_{i s t}=\alpha+\gamma \text { Treatment }_{i}+\varphi \text { After }_{t}+\beta \text { Treatment }_{i} * \text { After }_{t}+X_{i t} \delta+\mu_{s}+\pi_{s t}+\varepsilon_{i s t}
$$

where $Y_{i s t}$ is the outcome of interest and measures the average age of politicians elected in locality $i$, in province $s$, in year $t$; Treatment $i$ and After $_{t}$ are, respectively, dummy variables for municipalities affected by gender quotas and for elections taking place after the introduction of the reform, as already described. The variable Treatment allows us to control for the unobserved time-invariant characteristics that may differ across municipalities in the two groups, whereas the variable After captures the temporal trend common to both groups. More precisely, the variable After does also account for the impact of other provisions of the 1993 reform that affected all Italian municipalities. Treatment $_{i} *$ After $_{t}$ is the interaction term between the two dummies and measures the treatment effect of our interest. $X_{i t}$ is a vector of control variables including the population size, its square, the share of population over age 65, the share of university graduates and the share of employed resident population at the municipal level. We also include dummies for each province to account for the characteristics that are common to municipalities in the same province and are constant over time and indicate them with $\mu_{s} . \pi_{s t}$ is the interaction between province dummies and the dummy After accounting for time and province-varying shocks in the outcome variable. The inclusion of $\pi_{s t}$ guarantees that time-varying unobserved characteristics common to municipalities within the same province do not drive our results. Finally, $\varepsilon_{i s t}$ is an error term.

\section{Results}

Table 2 presents the results of our main specification. Panel A focuses on the effect of the reform on the average age of all members of the municipal council; Panel B and Panel $\mathrm{C}$ replicate the same set of regressions on female and male politicians respectively, 
to investigate the existence of differential effects according to the gender of the elected politician. In all panels, column 1 reports estimates of equation 1 without considering control variables, province and province-After dummies. In column 2 we include province dummies, in column 3 we add control variables and in column 4 we estimate the full specification in equation 1 . Standard errors are clustered at the province level. ${ }^{8}$

[Table 2 here]

We observe that treatment and control group municipalities do not significantly differ in terms of the average age of municipal councilors and that this variable remains roughly the same in the After with respect to the Before elections (see Panel A). ${ }^{9}$ However, the coefficient on the interaction term Treatment $*$ After is statistically significant and negative in all columns. The estimates suggest that the reform reduced the average age of the elected municipal councilors. Namely, after the introduction of the reform the average age of municipal councilors in the treatment group municipalities decreased by 1.12 to 1.37 years more than in the control group.

We then divide the sample according to the gender of the elected councilors. The dependent variable in Panel B is the average age of the elected female politicians. As the coefficient of interest is imprecise to the conventional confidence levels in all columns, we cannot claim that in the treatment municipalities the age of the elected women did evolve differently after the reform compared to the control group. Note, however, that the introduction of gender quotas still contributes to the average change in the age of the elected politicians through its compositional effect. Namely, more women are elected due to gender quotas (see De Paola et al., 2010, Baltrunaite et al., 2014) and female politicians are on average younger than male politicians.

The regressions on the age of the elected male in Panel $\mathrm{C}$ show that the age of male politicians experienced a larger reduction in the municipalities affected by the reform than in the control group. The results indicate that the age of male municipal councilors decreased by 0.87-1 year more in the treatment group than in the control group. Therefore, our estimates in the baseline specification are mainly driven by the reduction in the age of the elected men rather than of the elected women.

\footnotetext{
${ }^{8}$ The results are robust to clustering the standard errors at the municipality level.

${ }^{9}$ Due to the inclusion of province dummies interacted with the dummy After, the significant coefficient in column 4 is not informative about the change in the average age of the elected politicians in the After with respect to the Before elections.
} 
To better qualify the result according to which the age of the municipal councilors decreases more in treated municipalities, we compute the variance of age in municipal councils and use it as a dependent variable in our regressions. Table 3 shows that in the treated municipalities the variance decreased more than in the control group municipalities. Given that the average age and the variance go down, the decrease in the average age of politicians prompted by gender quotas does not hinge on the entry of a small number of very young individuals.

[Table 3 here]

To verify the robustness of our results, we control for political variables which may also have an impact on the age of politicians. First, one may argue that, given the staggered timing of municipal elections in the treatment and control group, it is possible that the effects on the politicians' age are mainly driven by changes in the winning parties' ideology. We therefore explicitly control for the political ideology of the majority in municipal councils. Namely, the vector of municipality-level control variables is augmented with dummies for the political leaning of the majority in the council. The distribution of councils according to this dimension can be found in Table 1 .

[Table 4 here]

Table 4 shows that our results are robust to controlling for the political ideology of the majority. In column 1 , the coefficient of interest Treatment* After on the average age of all members of the municipal council remains negative and statistically significant. The results for female and male politicians separately are shown, respectively, in column 2 and 3. The point estimates change their magnitude only slightly when compared to the corresponding columns in Table 2. This piece of evidence suggests that the results are not driven by differences in the winning parties' composition across elections taking place on different dates.

Second, we control for the level of political competition in the municipalities. We want to check whether the impact of quotas on age remains significant when controlling for the extent of political competition. We measure the latter by computing the difference between the number of seats of the winning majority and that of the second largest party group. The larger this difference is, the lower the level of political competition. Columns 4-6 in Table 4 show that indeed a stronger political competition is associated with a lower 
average age of municipal councilors. Our coefficient of interest is negative and significant in all regressions.

Overall, our results show that the introduction of gender quotas decreased the average age of individuals who became politicians in the municipalities affected by the policy: the age of the overall political body decreased by more in the treatment group municipalities than in control ones. This result is due to the fact that fewer old male politicians were elected. Given the lack of data on candidates' lists, we cannot disentangle whether these results are driven by optimizing behavior of parties or of voters. We now discuss each of the two possible mechanisms separately, keeping the other one fixed. As far as parties are concerned, gender quotas impose a constraint on candidates' choice by party leaders, since lists must now include a lower number of males compared to the unconstrained choice before the reform. Since parties are maximizing the expected number of votes, they must re-optimize the choice of male candidates present on the list. The significant reduction in the age of male politicians suggests that older men are of a lower expected valence in gaining votes for the party. This is in line with the findings of Lawson et al. (2010) that too old (or too young) candidates have a negative effect on electoral performance. The observed increase in the number of elected young male politicians may also be the result of changes of voting behavior. Even if parties did not alter the age composition of the male candidates, by their revealed preferences, voters consider younger male politicians better and thus they voted for them. ${ }^{10}$

Our evidence documents the presence of a significant spill-over effect of affirmative action policies targeted to raising female participation in politics on political selection mechanisms more in general. Since the existing literature shows that age is relevant for both the leadership style and the policies implemented, the overall assessment of the appropriate age profile of a political body depends on the specific context. For instance, if youth unemployment is a top priority, younger politicians are likely to tackle this issue better (Marques, 2013). Similarly, if renovation of the existing political elite is needed, policy actions that rebalance the age (and gender) of the ruling class may be desirable (Besley et al., 2013). On the contrary, if experience and accumulated knowhow are required, for instance, due to a conflictual environment, older politicians may be preferred, as analyzed by Spisak (2012).

\footnotetext{
${ }^{10}$ Isolating the age-based voting decisions is a complex empirical issue. Previous studies find divergent results. Campbell and Cowley (2013) show that candidates' age has a negligible effect on voters' choices. Cutlers (2002) argues that sociodemographic similarities between voters and candidates matter for their decision on whom to vote for.
} 


\section{Concluding remarks}

A male gerontocracy seem to dominate the political arena in several countries. The aging process is expected to exacerbate this trend. Both the age and gender of politicians matter: they may influence the style of leadership, the productivity of decision makers and their policy agenda. Whereas gender quotas have been adopted and/or discussed in several countries as a policy to increase the role of women in politics, the issue of a more balanced representation by age has been relatively neglected both in the debate and in research.

We argue that gender quotas may be a useful policy to improve not only representation by gender but also by age, due to their spill-over effect on the reduction of the age of elected politicians. Applying a Difference in differences approach to a quasi-natural experiment on Italian municipalities, our results show that indeed gender quotas are associated with the election of younger politicians. This result, which is particularly meaningful in an aging world, extends the success of actions targeted to the promotion of gender equality, as they turn to be a powerful mechanism to renovate the current ruling class.

\section{References}

[1] Baltrunaite, A., Bello, P., Casarico, A. and Profeta, P. (2014). "Gender Quotas and the Quality of Politicians", Journal of Public Economics, forthcoming.

[2] Barbuto, J., Fritz, S., Matkin, G. and Marx, D. (2007). "Effects of gender, education, and age upon leaders use of influence tactics and full range leadership behaviors", University of Nebraska, Faculty publications: Agricultural Leadership, Education \& Communication Department. Paper 40.

[3] Besley, T., Folke, O., Persson, T. and Rickne, J. (2013). "Gender quotas and the crisis of the mediocre man: Theory and evidence from Sweden", mimeo, IIES, Stockholm University.

[4] Börsch-Supan, A. and Weiss, M. (2011). "Productivity and age: Evidence from work teams at the assembly line", MEA discussion paper series 07148. 
[5] Campa, P., Casarico, A. and Profeta, P. (2011). "Gender Culture and Gender Gap in Employment", CESifo Economic Studies, 57(1): 156-182.

[6] De Paola, M., Scoppa, V. and Lombardo, R. (2010). "Can gender quotas break down negative stereotypes? Evidence from changes in electoral rule", Journal of Public Economics, 94(5-6): 344-353.

[7] Gagliarducci, S. and Paserman, D. (2012). "Gender Interactions within Hierarchies: Evidence from the Political Arena", Review of Economic Studies, 79: 1021-1052.

[8] Galasso, V. and Nannicini, T. (2011). "Competing on Good Politicians", American Political Science Review, 105(1): 79-99.

[9] Galasso, V. and Profeta, P. (2004). "Lessons for an Ageing Society: the Political Sustainability of Social Security Systems", Economic Policy: 63-115.

[10] Galasso, V. and Profeta, P. (2007). "How Does Ageing Affect the Welfare State?", European Journal of Political Economy, 23: 554-563.

[11] Lau, R. R. and Redlawsk, D. P. (2008). "Older but Wiser? Effects of Age on Political Cognition", The Journal of Politics, 70 (1): 168-185.

[12] Lawson, C., Lenz, G. S., Baker, A. and Myers, M. (2010). "Looking like a winner: candidate appearance and electoral success in new democracies", World Politics, 4: 561-593.

[13] Lovenduski, J. and Norris, P. (2003). "Westiminster women: the politics of presence", Political Studies, 51: 84-102.

[14] Marques, D. (2013). "Young politicians: different politics?", European view.

[15] Merlo, A., Galasso, V., Landi, M. and Mattozzi, A. (2009). "The Labor Market of Italian Politicians", in T. Boeri, A. Merlo and A. Pratt (2010), eds., The ruling class: management and politics in modern Italy, Oxford University Press.

[16] Mulligan, C.B. and Sala-i-Martin, X. (2003) "Social Security, Retirement, and the Single-Mindedness of the Electorate", NBER Working Paper 9691.

[17] Razin, A., Sadka, E. and Swagel, P. (2002). "The ageing population and the size of the welfare state", Journal of Political Economy, 110: 900-918. 
[18] Schubert, J., Wiegele, T. and Hines, S. (1987). "Age and political behavior in collective decision making", International Political Science Review, 8 (2): 131-146.

[19] Schubert, J. N. (1988). "Age and Active-Passive Leadership Style", The American Political Science Review, 82 (3): 763-772.

[20] Simonton, D. K. (1984). "Leader age and national condition: A longitudinal analysis of 25 European monarchs", Social Behavior and Personality, 12: 111-114.

[21] Simonton, D.K. (1988). "Age and Outstanding Achievement: What Do We Know After a Century of Research?", Psychological Bulletin, 104(2): 251-267.

[22] Spisak, B. (2012) "The general age of leadership: older looking presidential candidates win elections during war ", PLoS ONE 7(5): e36945.

[23] Wegge, J. and Schmidt, K.-H. (2009). "The impact of age diversity in teams on group performance, innovation and health", in A.-S. G. Antoniou and E. Elgar, eds., Handbook of Managerial Behavior and Occupational Health., Edward Elgar Publishing, 79-94.

[24] Wiersema, M. F. and Bantel, K. A. (1992). "Top Management Team Demography and Corporate Strategic Change", Academy of Management Journal, 35(1): 91-121. 


\section{Figures and tables}

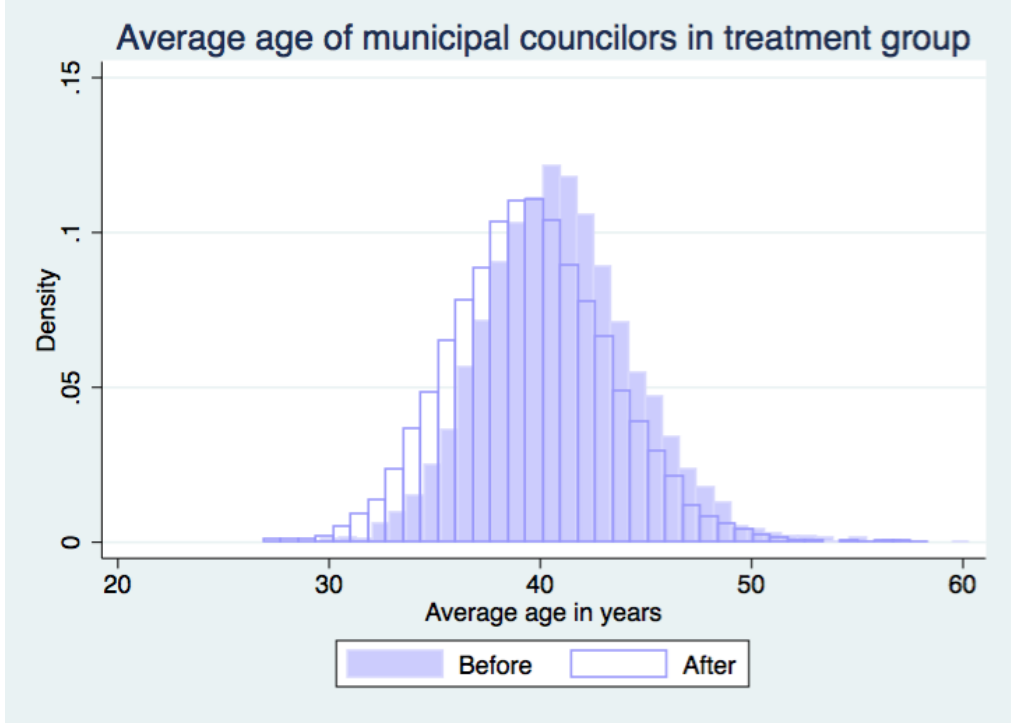

Figure 1: Average age before and after the introduction of gender quotas 
Table 1: Baseline covariates

\begin{tabular}{|c|c|c|c|}
\hline & Treatment & Control & Difference \\
\hline Population & 5926.50 & 5468.58 & -457.922 \\
\hline se & $(431.137)$ & $(569.214)$ & $(1834.29)$ \\
\hline $\mathrm{N}$ & 7633 & 424 & \\
\hline Population over 65 & 0.18392 & 0.17062 & $-0.01329 * * *$ \\
\hline se & 0.00074 & 0.00305 & 0.00323 \\
\hline $\mathrm{N}$ & 7632 & 424 & \\
\hline Employment rate & 0.41311 & 0.37945 & $-0.03365^{* * *}$ \\
\hline se & $(0.00101)$ & $(0.00444)$ & $(0.00443)$ \\
\hline $\mathrm{N}$ & 7633 & 424 & \\
\hline Female employment rate & 0.27145 & 0.24594 & $-0.02551^{* * *}$ \\
\hline se & $(0.00099)$ & $(0.00445)$ & $(0.00435)$ \\
\hline $\mathrm{N}$ & 7633 & 424 & \\
\hline Local education level & 0.02081 & 0.02095 & 0.00014 \\
\hline se & $(0.00016)$ & $(0.00068)$ & $(0.00070)$ \\
\hline $\mathrm{N}$ & 7633 & 424 & \\
\hline Located in the South & 0.25657 & 0.49765 & $0.241078^{* * *}$ \\
\hline se & $(0.00500)$ & $(0.02425)$ & $(0.02192)$ \\
\hline $\mathrm{N}$ & 7643 & 426 & \\
\hline Center-right majority & 0.43177 & 0.47183 & 0.04006 \\
\hline se & $(0.00567)$ & $(0.02422)$ & $(0.02467)$ \\
\hline $\mathrm{N}$ & 7643 & 426 & \\
\hline Left-wing majority & 0.47377 & 0.42254 & $-0.051232^{* *}$ \\
\hline $\mathrm{se}$ & $(0.00571)$ & $(0.02396)$ & $(0.02485)$ \\
\hline $\mathrm{N}$ & 7643 & 426 & \\
\hline Civic list majority & 0.06817 & 0.07512 & 0.00695 \\
\hline se & $(0.00288)$ & $(0.01279)$ & $(0.01258)$ \\
\hline $\mathrm{N}$ & 7643 & 426 & \\
\hline Coalition majority & 0.02630 & 0.03052 & 0.00422 \\
\hline se & $(0.00183)$ & $(0.00834)$ & $(0.00800)$ \\
\hline $\mathrm{N}$ & 7643 & 426 & \\
\hline Political competition & 0.45619 & 0.43135 & $-0.02484^{*}$ \\
\hline se & $(0.00313)$ & $(0.01346)$ & $(0.01361)$ \\
\hline $\mathrm{N}$ & 7643 & 426 & \\
\hline
\end{tabular}

Note. Pre-treatment baseline covariates in treatment and control municipalities and their difference. Covariates are: population over age 15 (Population), employment rate (Employment rate), female employment rate (Female employment rate), share of university graduates (Local education level), share of municipalities located in the South (Located in the South), share of municipalities with center-right majority (Center-right majority), with left-wing majority (Left-wing majority), with civic list majority (Civic list majority) and with coalition majority (Coalition majority), political competition (Political competition) defined as the difference between the seats' share received by the majority and by the second largest party group. Standard errors are in parenthesis. The following symbols indicate different significance levels: $* * *$ - significant at $1 \%, * *$ - significant at $5 \%,{ }^{*}$ significant at $10 \%$. 
Table 2: Average age of council members

\begin{tabular}{|c|c|c|c|c|}
\hline \multicolumn{5}{|c|}{ Panel A: all politicians } \\
\hline & (1) & $(2)$ & (3) & (4) \\
\hline Treatment & $\begin{array}{c}0.106 \\
(0.184)\end{array}$ & $\begin{array}{l}-0.180 \\
(0.155)\end{array}$ & $\begin{array}{l}-0.197 \\
(0.155)\end{array}$ & $\begin{array}{c}-0.0748 \\
(0.158)\end{array}$ \\
\hline After & $\begin{array}{l}-0.115 \\
(0.238)\end{array}$ & $\begin{array}{c}-0.118 \\
(0.232)\end{array}$ & $\begin{array}{c}-0.250 \\
(0.230)\end{array}$ & $\begin{array}{c}-2.179 * * * \\
(0.240)\end{array}$ \\
\hline Treatment*After & $\begin{array}{c}-1.249^{* * *} \\
(0.237)\end{array}$ & $\begin{array}{c}-1.248^{* * *} \\
(0.229)\end{array}$ & $\begin{array}{c}-1.123^{* * *} \\
(0.228)\end{array}$ & $\begin{array}{c}-1.371^{* * *} \\
(0.240)\end{array}$ \\
\hline Observations & 16,225 & 16,225 & 16,197 & 16,197 \\
\hline R-squared & 0.033 & 0.169 & 0.217 & 0.236 \\
\hline \multicolumn{5}{|c|}{ Panel B: female politicians } \\
\hline & (1) & $(2)$ & $(3)$ & (4) \\
\hline Treatment & $\begin{array}{l}-0.294 \\
(0.544)\end{array}$ & $\begin{array}{l}-0.614 \\
(0.549)\end{array}$ & $\begin{array}{l}-0.552 \\
(0.547)\end{array}$ & $\begin{array}{l}-0.453 \\
(0.569)\end{array}$ \\
\hline After & $\begin{array}{l}-0.444 \\
(0.581)\end{array}$ & $\begin{array}{c}-0.266 \\
(0.580)\end{array}$ & $\begin{array}{c}-0.296 \\
(0.570)\end{array}$ & $\begin{array}{c}-1.437^{* *} \\
(0.576)\end{array}$ \\
\hline Treatment*After & $\begin{array}{l}-0.570 \\
(0.587)\end{array}$ & $\begin{array}{c}-0.599 \\
(0.588)\end{array}$ & $\begin{array}{l}-0.499 \\
(0.579)\end{array}$ & $\begin{array}{l}-0.668 \\
(0.579)\end{array}$ \\
\hline Observations & 13,708 & 13,708 & 13,682 & 13,682 \\
\hline R-squared & 0.005 & 0.044 & 0.082 & 0.090 \\
\hline \multicolumn{5}{|c|}{ Panel C: male politicians } \\
\hline & (1) & $(2)$ & (3) & (4) \\
\hline Treatment & $\begin{array}{c}0.253 \\
(0.193)\end{array}$ & $\begin{array}{l}-0.103 \\
(0.164)\end{array}$ & $\begin{array}{l}-0.123 \\
(0.163)\end{array}$ & $\begin{array}{c}-0.0106 \\
(0.166)\end{array}$ \\
\hline After & $\begin{array}{c}0.259 \\
(0.247)\end{array}$ & $\begin{array}{c}0.255 \\
(0.240)\end{array}$ & $\begin{array}{c}0.133 \\
(0.239)\end{array}$ & $\begin{array}{c}-2.369^{* * *} \\
(0.262)\end{array}$ \\
\hline Treatment*After & $\begin{array}{c}-0.995^{* * *} \\
(0.251)\end{array}$ & $\begin{array}{c}-0.988^{* * *} \\
(0.244)\end{array}$ & $\begin{array}{c}-0.872^{* * *} \\
(0.244)\end{array}$ & $\begin{array}{c}-1.099^{* * *} \\
(0.262)\end{array}$ \\
\hline Observations & 16,225 & 16,225 & 16,197 & 16,197 \\
\hline R-squared & 0.009 & 0.149 & 0.185 & 0.203 \\
\hline Province FE & NO & YES & YES & YES \\
\hline Controls & NO & NO & YES & YES \\
\hline Province FE*After & NO & NO & NO & YES \\
\hline
\end{tabular}

Note. OLS regressions of average age of council members. Panel A shows the results for all politicians, Panel B - for females and Panel C - for males. The sample contains the last election before the adoption of gender quotas and the first election after the adoption of this provision for every Italian municipality. For treated (control) municipalities, After elections are held when the gender quota is in force (no longer in force). Columns 2-4 include province dummies; columns 3-4 control for the municipality employment rate, the share of university graduates, the share of population over age 65, population over age 15 and its square (coefficients of the control variables are not reported); column 4 includes interactions between province dummies and the dummy After. Standard errors clustered at province level are in parenthesis. The following symbols indicate different significance levels: $* * *$ - significant at $1 \%$, ** significant at 5\%, * - significant at $10 \%$. 
Table 3: All politicians

\begin{tabular}{lccc}
\hline \multicolumn{4}{c}{ Variance of age of council members } \\
\hline VARIABLES & $(1)$ & $(2)$ & $(3)$ \\
& All & Female & Male \\
\hline \multirow{3}{*}{ Treatment*After } & $-9.557^{* * * *}$ & $-16.85^{*}$ & $-9.609^{* * *}$ \\
& $(3.287)$ & $(9.918)$ & $(3.506)$ \\
& & & \\
Observations & 16,197 & 10,467 & 16,197 \\
R-squared & 0.179 & 0.043 & 0.160 \\
Province FE & YES & YES & YES \\
Controls & YES & YES & YES \\
Province FE*After & YES & YES & YES \\
\hline
\end{tabular}

Note. The table reports the Difference in differences coefficient from OLS regressions of variance of age of councilors. Treatment and After dummies are included in the regression, but their coefficients are not reported. The sample contains the last election before the adoption of gender quotas and the first election after the adoption of this provision for every Italian municipality. For treated (control) municipalities, After elections are held when the gender quota is in force (no longer in force). All columns include province dummies and interactions between province dummies and the dummy After. All columns control for the municipality employment rate, the share of university graduates, the share of population over age 65, population over age 15 and its square (coefficients of the control variables are not reported). Column 1 shows the results for all councilors, column 2 - for female councilors and column 3 - for male councilors. Standard errors clustered at province level are in parenthesis. The following symbols indicate different significance levels: $* * *$ - significant at $1 \%$, ** - significant at $5 \%,{ }^{*}$ - significant at $10 \%$. 
Table 4: Political variables

\begin{tabular}{lcccccc}
\hline \multicolumn{7}{c}{ Average age of council members } \\
\hline VARIABLES & $(1)$ & $(2)$ & $(3)$ & $(4)$ & $(5)$ & $(6)$ \\
& All & Female & Male & All & Female & Male \\
\hline Treatment*After & $-1.358^{* * *}$ & -0.672 & $-1.082^{* * *}$ & $-1.391^{* * *}$ & -0.721 & $-1.112^{* * *}$ \\
& $(0.245)$ & $(0.577)$ & $(0.267)$ & $(0.242)$ & $(0.572)$ & $(0.264)$ \\
Left-wing majority & $-0.305^{* * *}$ & $-0.446^{* *}$ & $-0.208^{* *}$ & & & \\
& $(0.0873)$ & $(0.190)$ & $(0.0903)$ & & & \\
Civic list majority & -0.0936 & -0.334 & 0.0292 & & & \\
& $(0.151)$ & $(0.253)$ & $(0.161)$ & & & \\
Coalition majority & 0.0272 & 0.649 & -0.0134 & & & \\
& $(0.165)$ & $(0.499)$ & $(0.166)$ & & & \\
Political competition & & & & $-0.630^{* * *}$ & $-1.329^{* * *}$ & $-0.411^{* * *}$ \\
& & & & $(0.109)$ & $(0.220)$ & $(0.117)$ \\
Observations & 16,197 & 13,682 & 16,197 & 16,197 & 13,682 & 16,197 \\
R-squared & 0.237 & 0.091 & 0.204 & 0.238 & 0.092 & 0.204 \\
Province FE & YES & YES & YES & YES & YES & YES \\
Province FE*After & YES & YES & YES & YES & YES & YES \\
\hline
\end{tabular}

Note. The table reports the Difference in differences coefficient from OLS regressions of average age of council members. Treatment and After dummies are included in the regression, but their coefficients are not reported. The sample contains the last election before the adoption of gender quotas and the first election after the adoption of this provision for every Italian municipality. For treated (control) municipalities, After elections are held when the gender quota is in force (no longer in force). All columns include province dummies and interactions between province dummies and the dummy After. All columns control for the municipality employment rate, the share of university graduates, the share of population over age 65, population over age 15 and its square (coefficients of the control variables are not reported). Columns 1-3 include dummies for left-wing majority (Left-wing majority), civic list majority (Civic list majority) and coalition majority (Coalition majority). Center-right majority is used as excluded category. Columns 4-6 control for electoral competition (Political competition) defined as the difference between the seats' share received by the majority and by the second largest party group. Columns 1 and 4 show the results for all councilors, columns 2 and 5 - for female councilors and columns 3 and 6 - for male councilors. Standard errors clustered at province level are in parenthesis. The following symbols indicate different significance levels: $* * *$ - significant at $1 \%,{ }^{* *}$ - significant at $5 \%,{ }^{*}$ - significant at $10 \%$. 